\title{
Reviews
}

\section{Joela Jacobs}

\section{Animal Answers to the Jewish Question}

Jay Geller. Bestiarium Judaicum: Unnatural Histories of the Jews. New York: Fordham University Press, 2018. 404 pp. \$75 hb.

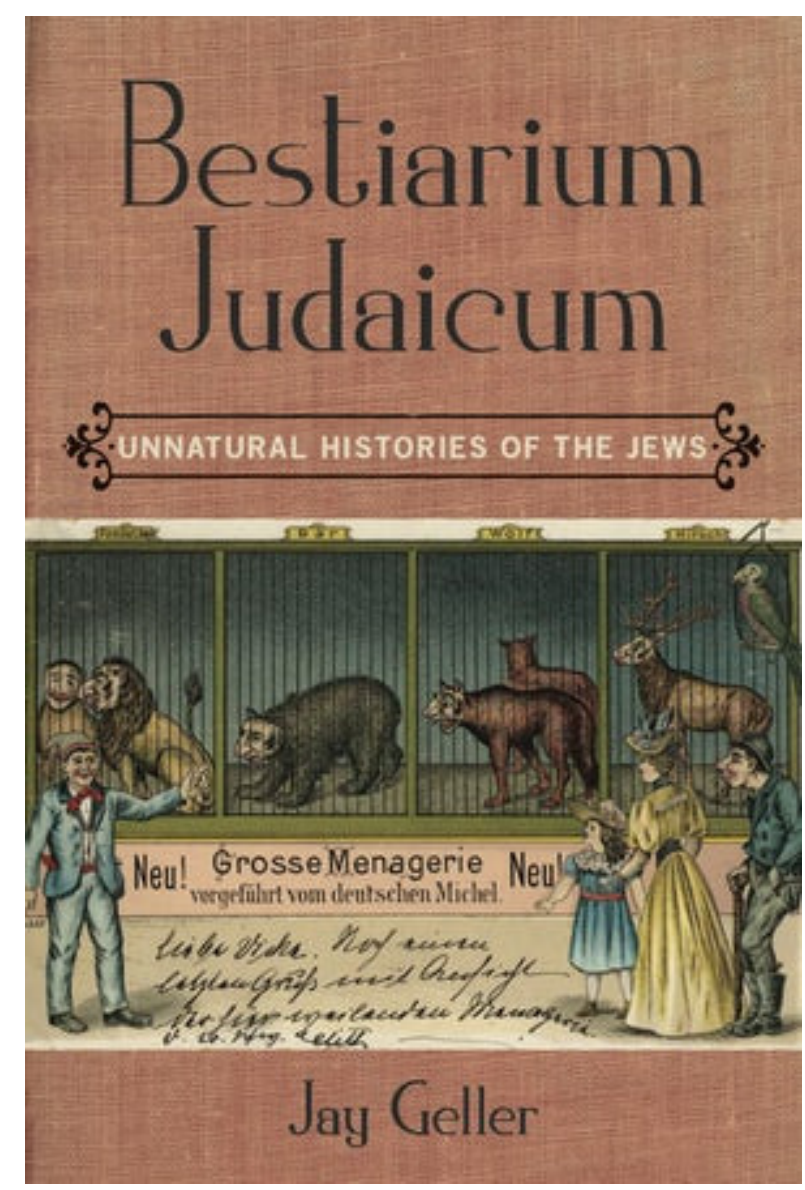

In Bestiarium Judaicum, Jay Geller brings together the Jewish Question with the question of the animal. He explores the ways in which Jews, particularly in German-speaking European Modernity (between 1750 and the Shoah), have been dehumanized through images of animals, and how they, in turn, have written back to undermine these antiSemitic stereotypes with animal figures of their own. The animalization of Jews 
produces, in Geller's words of the introduction, "Jew-Animals" (5), and in his first chapter, he reaches back to ancient and medieval sources to sketch the harrowing history of associating Jews with specific animals, such as pigs, apes, wolves, and vermin. This act of bestialization renders Jews killable and has been used as justification for genocide, slavery, and exploitation in many contexts. The following seven chapters of Bestiarium Judaicum engage with predominantly nineteenth- and twentieth-century literature featuring animal figures, written by German-Jewish writers such as Heinrich Heine and Franz Kafka. In his analyses of these works, Geller shows how the authors take up the species-specific stereotypes of the Jew-Animal and undermine it by "performing animal, the Jew-as-Animal, by literalizing their societally figured identifications (i.e., the Jew-Animal)" (21). In attending to the authors' specific sociohistorical contexts and the particularities of individual animal figures, Geller localizes instances of Jewish writers turning the animalization of Jews (Jew-Animals) into a literary performance of the Jew-as-Animal that undermines these stereotypes by literalizing them and exposing their constructedness.

A study about Jews and animals has to negotiate many difficulties that come with such a comparison, and Geller carefully addresses the inherent dangers of ascribing the literary strategy of performing the Jew-as-Animal to these works. Rather than assuming that all of the texts in his canon undermine the animalization of Jews, readers should expect to find that some analyses remain purposefully inconclusive on this question in order not to overdetermine the work under discussion. Undecidability is, in fact, one of the aesthetic strategies that Geller considers to be central in particular to Kafka's animal figures, who remain hovering between human and animal species designations and, similarly, cannot always be conclusively identified as a "Jewish animal" either. From the outset, Geller also emphasizes that his study does not engage with the Holocaust in the way readers might expect when thinking, for instance, of Jews led "like sheep to the slaughter" in cattle cars (which is another example of the Jew-Animal, as the afterword establishes). Rather, Bestiarium Judaicum demonstrates that the pervasive history of associating Jews with animals has to be considered in a much broader time frame, with diverse appropriations by various people for many purposes, and, most importantly, that centuries of Jewish history and literary production should not be read through the retrospective lens of the Shoah.

Chapter one draws on a variety of sources, ranging from ancient texts to medieval treatises, and from proverbs to visual media that assemble an inventory of negative associations of Jews with animals. In its variety, the chapter is exemplary for the host of references and striking illustrations reprinted in Bestiarium Judaicum as a whole. Geller shows convincingly that the biologistic shift of modernity only reinforced the inherited 
inventory of animal imagery: "Where once associating 'The Jew' with apes or parrots was tied to the Devils' imitatio dei and dissimulation it became grounded in an innate mimetic capacity that the animal employs to preserve itself and to prey on others; similarly, the association with vermin shifted from the discourse of sin and subjection to that of disease and parasitology" (46). The chapter ties these developments to the taxonomical thinking informing nationalist endeavors, which resulted in the modern paradox by which Jews were both said to be so adept at "aping" their Gentile neighbors that they would achieve perfect assimilatory success and become indistinguishable, yet be denied acceptance and equal rights due to the dictum of their "unchangeable Jewish essence" that differentiated them. Among other examples, Geller demonstrates this through the legal requirement of last names for the Jewish population, which resulted in many animal choices, such as Hirsch (stag/Naftali), Wolf(f) (wolf/Benjamin), and Loew(y) (lion/Judah), since these represented the tribes of Israel, while Gentile name choices, which predominantly represented professions (such as Müller/Miller and Schmidt/Smith), were prohibited. Of course, these ferocious animal names often came at a price and officials also frequently handed out demeaning animal names. Instead of carrying occupations in the family name, the word "Jew" was increasingly appended to professions (e.g., Viehjude/cattle Jew) in order to distinguish Gentiles and Jews once more, and these terms took on a life of their own as insults, just as the wild animal names designating the tribes of Israel became incorporated into the inventory of antiSemitic stereotypes. Throughout these discussions, Geller demonstrates that "identifying Jewish animality was often disseminated by phonemic, orthographic, and morphemic semes" (49).

The study's close attention to semantics also shows in Geller's own writing and the many word plays that operate throughout Bestiarium Judaicum, particularly its titles. The reader encounters, for instance, "Semitic Simiantics" in chapter four, and Geller's research interest in Jewish masculinity come through in the suggestive excursions connecting (rat/mouse, lizard, and wolf/dog) tails to braids and circumcised penises on several occasions. It is precisely this focus on evocative language that enables Bestiarium Judaicum to pursue new angles in the discussion of texts such as Kafka's, which have been famously analyzed to excess. By weaving together the authors' literary production with their socio-historical contexts, established through letters, diary entries, and explorations of the interactions and sometimes pesky politics of literary networks, the book outlines their specific Bestiarium Judaicum, that is, the writers' menagerie of Jewish animals. Even though the book translates all original sources, the reader is well served with some knowledge of German as well as Jewish terminology (i.e., traditions, history, and important Hebrew and Yiddish phrases). The few central concepts drawn from

Humanimalia: a journal of human/animal interface studies

Volume 10, Number 2 (Spring 2019) 
Animal Studies, on the other hand, are introduced in detail, so that it becomes clear that the intended audience for this study will be primarily at home in German-Jewish Studies, rather than Animal Studies - also due to the book's primary focus on the human-produced and human-suffered side of animalization. Nonetheless, Bestiarium Judaicum provides something that is often absent in the widespread engagement with particularly Kafka's oeuvre by Animal Studies scholars, namely deep knowledge of the many extant fragments and relevant other writings pertaining to the literary text, in the original language.

In chapter two, Geller discusses Kafka's The Metamorphosis (1912/1915) and "Josephine the singer, or the Mouse Folk" (1924) to show that both the undecidability of species designation and the identification of these figures as Jewish "confronted their readers with the constructedness of both human/animal difference and species essentialism and thereby intervened, whether effectively or not, against an apparatus that these two constructs conditioned, an apparatus that helped naturalize both Gentile/Jew difference and the violent means sustaining it" (58). Connecting the figure of the singing, or rather piping, Maus (mouse) with the notion of mauscheln (speaking a language inflected by one's Jewishness), the analysis showcases a wide array of anti-Semitic stereotyping (such as Wagner's 1850/1869 rant against Judaism in Music, to which Geller returns in more detail in chapter four) and Jewish artistic production (such as Art Spiegelman's 1986 Maus) that draw on vermin (Ungeziefer, or Untiere/un-animals, such as bugs, mouse, rats). In chapter three, cats join these mice in the discussion of Jewish conversion to Christianity as an impossible way out of the violent cat and mouse play in Kafka's "Little Fable" (ca. 1920/1931) and Heine's poem "From the Age of Pigtails" (ca. 1852-55). For scholars of German-Jewish studies, the most compelling intervention of this chapters might be Geller's way of bringing together Kafka and Heine, and his elucidation of the intricacies of defining Judentum (Jewishness) in the Verein für Cultur und Wissenschaft der Juden ("the society for the [promulgation of the] culture and scholarly study [or science] of and by Jews," 82); while Animal Studies scholars will likely be smitten by Kafka's own Derridean naked encounter (or rather, then, Derrida's Kafkaesque encounter) with a cat in his pursuit to get rid of mice in the sanatorium (see 86).

Chapter four expands on the notion of undecidability as part of Kafka's aesthetics and picks up on the accusation of imitation in the Jewish "reproductive arts, such as acting, musical performance, and journalism" (109) broached in chapter two, by engaging with "The Report to an Academy" (1917) and returning to Josephine. Continuously considering the two options of the Jew-Animal and the Jew-as-Animal side-by-side, this particularly lucid and convincing chapter on mimesis and mimicry concludes that 
"Kafka's creations do not present the Jews as the dominant anti-Semitic society's 'Other,' the monstrous animal-object created by Gentile, bourgeois fears and hatreds. Rather, he presents individuals and groups whose identifications are shaped by their interpellation into such a society" (137).

Chapters five and six are joined by similar titles and their focus on lizards; the first of them traces these saurian critters across of the works of Max Brod in relation to Kafka, as well as in Heine's writing, and the second turns to Felix Salten's Bambi (1923). Chapter five engages with Judith Butler's response to the recent trial regarding the future location of a suitcase of Kafka's writings in an archive in Germany or Israel, toward which Geller positions himself quite clearly. The chapter's examination of the historical sources shows the importance of avoiding assumptions about the meaning of animal ciphers without considering their context. While the contemporary debates are important, some of the literary politics in chapters such as three, five, and seven occasionally detract from the book's own argument. Chapter six contextualizes both Bambi and Bambi's Children (1940) while arguing that some of the allegorical understandings of the text have flattened complicated nuances in their equation of the hunted forest animals with the fight for Jewish survival in Europe. Particularly noteworthy for its unusual imagery in this discussion is Heine's notion of Jews as Hühneraugen (literally hen's eyes, meaning corn) on the foot of the German nation (see 166).

Chapter seven attends to Kafka's "Jackals and Arabs" (1917) by dismantling an article by Jens Hanssen that is "enlisting them to decry so-called settler-colonialist Zionism in 1917 and today" (170). This critique is motivated by the term Gattung (meaning genre and genus) and argues against allegorical readings that erase Kafka's undecidability in favor of interpretations that map too neatly onto contemporary concerns in theory and politics. In this context, Geller also draws on Kafka's canine references, especially "Investigations of a Dog" (1922/1931), in order to demonstrate that "Kafka's animal figuration defies any attempt at determinate allegorical identification, let alone attempting to revalorize alleged Jewish caninity" (182). The final chapter moves from jackals and dogs to wolves, particularly werewolves, in the following works: Freud's "Wolf-Man," H. Leivick's Yiddish werewolf narrative The Wolf (1920), Heine's characterization of Jewish characters like Shakespeare's Shylock in 1838 and the consort of "Princess Sabbath" (1851), and Curt Siodmak's film script for The Wolf Man (1941). Despite this wealth of sources and the anti-Semitic identification of Jews with wolves and with blood-sucking monsters like vampires, Geller establishes that Jewish werewolves (as figures outside of the Law) were virtually absent from the European

Humanimalia: a journal of human/animal interface studies

Volume 10, Number 2 (Spring 2019) 
tradition until the twentieth century. In its masterful layering of references, this chapter extends an argument begun in chapter seven in respect to Kafka's work, by showing that "Heine rendered the purported Jewish referent of those interpellating identifications indefinite - that is, as both animal and human and neither; as both Jew and Gentile and neither - while Siodmak demonstrated the tragic consequences on individual lives of such oppressive identifications" (191). The return to Freud in this chapter, moreover, connects the argument to Geller's previous monographs, On Freud's Jewish Body: Mitigating Circumcisions (Fordham, 2007) and The Other Jewish Question: Identifying the Jew and Making Sense of Modernity (Fordham, 2011).

In the afterword, Geller engages with the animal poetry written in the 1930s by German-Jewish author Gertrud Kolmar, who perished at Auschwitz. The evocative imagery of her poem "Der Tag der grossen Klage," or "The Day of the Great Lament [or Accusation]" (222), reads "like a horrifying and horrifyingly prophetic allegory" (222) after Auschwitz, and simultaneously shows the poet's familiarity with Jewish traditions and religious imagery. "Just as the victimization of animals helped her figure the experience of German Jewry after the Nazi seizure of power," Geller writes, "so did the awareness of Judentum's traditions and history provide her with a framework to howl that große Klage against the torture, to which animals are subjected, and to envision their possible (divine) redress" (223). In these final pages, Geller carefully connects the suffering of Jews and animals by highlighting the many problematic implications of calling animal existence in an inhumane world "an eternal Treblinka" (citing the protagonist of Isaac Bashevis Singer's 1968 story "The Letter Writer" on 225). Engaging with central moments of reflection on animals in the writing of Holocaust survivors, such as Primo Levi, Emanuel Levinas, and Jiri Weil, Geller defines important differences between the animalization and objectification of humans, and he strongly rejects the supposed Jewish passivity implied in the "analogical identification of the Jew-Animal: "like [a] sheep to the slaughter'" (231) that invokes Isaiah 53:7. Ultimately, the book convincingly concludes that the many Jewish authors on its pages "sought to wrest from the Jew-Animal, wherever it roamed, its oppressive force whether by uncovering the conditions for its production in order to subvert its naturalization or by giving voice to the Jew-as-Animal and to the Jewish animot." (232) 